\title{
SENSITIVITY AND SPECIFICITY OF ATYPICAL LYMPHOCYTE FOR DIAGNOSIS OF DENGUE VIRUS INFECTION AT MATARAM HOSPITAL, WEST NUSA TENGGARA
}

\author{
Larantika Hidayati \\ Masters' Program in Immunology, Postgraduate School, \\ Universitas Airlangga, Surabaya
}

\begin{abstract}
Background: Diagnosis of dengue infection (DI) is done by anamnesis and physical examination, confirmed by laboratory examination. Currently, laboratory tests to deter-mine DI infection are isolation and identification of virus, antigen detection, and serological test. In human, dengue virus stimulates body to produce immunoglobulin M (IgM). The stimulation pathway is carried out through stimulation of lymphocytes B. Transitional forms between lymphocytes and plasma cells are seen in the blood of patients with viral infections. These cells are variously known as atypical lymphocyte. This study aimed to examine the sensitivity and specificity of atypical lymphocyte for diagnosis of dengue virus infection.

Subjects and Method: This was a cross-sectional study carried out at Mataram hospital, West Nusa Tenggara. A total of 26 blood samples was selected for this study, consisting of: 13 samples of DI positive and 13 samples of DI negative. The study variables of interest were sensitivity and specificity of atypical lymphocyte. The data were analyzed descriptively.

Results: Out of 13 samples with DI positive, 10 samples were atypical lymphocyte positive. Therefore, the sensitivity $=76.92 \%$. Out of 13 samples with DI negative, 11 samples were atypical lymphocyte negative. Therefore, the specificity $=84.61 \%$.

Conclusion: The sensitivity and specificity of atypical lymphocyte are $76.92 \%$ and $84.61 \%$, respectively, indicating atypical lymphocyte has relatively weak sensitivity and specificity for diagnoses of dengue virus infection.
\end{abstract}

Keywords: atypical lymphocyte, sensitivity, specificity, dengue infection

\section{Correspondence:}

Larantika Hidayati. Masters' Program in Immunology, Universitas Airlangga. Jl. Airlangga 4-6 Surabaya, East Java, Indonesia. Email: larantika19@gmail.com. Mobile: 08-7765038001

\section{BACKGROUND}

Dengue is the most widespread arboviral disease in the world, which is transmitted through the Aedes aegypti and Aedes albopyctus mosquitoes. Dengue virus consists of a single chain RNA that has four serotypes known as DEN-1, DEN-2, DEN-3, and DEN4. Infection from one of the virus serotypes causes flu-like symptoms called dengue fever (DF), with severe clinical symptoms called Dengue Hemorrhagic Fever (DHF) (Arruan, Rambert, \& Manopo, 2015).

Dengue infection is a systemic and dynamic disease that has a wide clinical spectrum which includes severe and non-severe clinical manifestations. After the incubation period, the disease starts suddenly and is followed by three stages - fever, critical and recovery (World Health Organization, 2009) In 1989-1995, epidemiological data in Indonesia showed that the incidence of DHF was 6-15 cases per 100,000 population (Afira \& Mansyur, 2013). DHF is a disease that is still a public health problem and endemic in some districts / cities in Indonesia. Almost every year Extraordinary Incident occur in some areas which usually occur during the rainy season. The number of sufferers tends to increase, its spread is increasingly widespread, attacking not only children but 
also older age groups (Widodo, 2012)

In the province of West Nusa Tenggara (NTB) during 2011, according to a report on the Disease Control Division of the NTB Provincial Health Office, 465 dengue cases were recorded. (NTB Provincial Health Office, 2012). From these data, it can be seen that the City of Mataram has the most cases of DHF in the NTB Province. Mataram City is an endemic area for DHF, because from 2003 to 2012, cases of DHF were always found (Widodo, 2012). According to data obtained at the Mataram City Hospital, during 2015 there were 303 cases of DHF and in 2016 it increased to 1372 cases, which means the incidence of dengue fever (DHF) is still very high.

Diagnosis of dengue fever patients is done by patient history taking, or alloanamnesis. Then proceed with a physical examination confirmed by a laboratory examination. Standard laboratory examinations submitted by WHO (1997) adopted by the Ministry of Health of the Republic of Indonesia for DHF are Thrombocytopenia and Torniquet Test. In addition to these examinations, tests that are commonly performed in patients with dengue hemorrhagic fever are peripheral blood examination consisting of hematocrit examination, platelet examination, and leukocyte examination (Purwanto, 2000).

Currently, laboratory tests to determine Dengue virus infection can be grouped into 3 groups, namely isolation and identification of viruses, antigen detection, and serological tests (Wiradharma, 1999).

Currently, Mataram Hospital Laboratory in the diagnosis of Dengue Hemorrhagic Fever (BBD) is known to use the Ns-1 examination and IgG-IgM examination which is the development of previous serolgi tests and platelet examination with Hematoanalyzer as a support. The advantage of the examination is the high accuracy but the examination requires a high enough cost so that not all laboratories can carry out the examination, especially laboratories with simple facilities.

Examination based on immunological determination, where the virus that causes DHF will provide stimulation for the patient's body to produce antibodies, namely in the form of immunoglobulin M (Ig M). The stimulation pathway is carried out through the stimulation of immunoglobulin-forming cells, namely lymphocytes B. B lymphocytes will experience stimulation, resulting in a plastic transformation that will be seen in peripheral blood in the form of the appearance of lymphocytes with blue plasma with giemsa staining. These Atypical lymphocyte cells can be identified in peripheral blood (Purwanto, 2002)

Atypical lymphocyte are reactive lymphocytes from lymphoid as an immune response with a percentage of $4 \%$ in peripheral blood and present in 98\% of Dengue Hemorrhagic Fever Cases. This increase was found on the third day to the seventh day of fever. The examination of atypical lymphocyte is a simple, inexpensive way to do it at the Health Center. The examination can help to make a diagnosis, especially in areas with simple laboratory facilities (Nany, 2003). However, examination with this method is very dependent on the process of painting blood preparations as well as the level of knowledge of a laboratory analyst about atypical lymphocyte .

The purpose of carrying out an examination is to, among others, test, diagnostic, evaluate treatment and surveillance results. Each examination objective requires different sensitivity and specificity, so the selection of methods to be used must be done because each method has different sensitivity and specificity (PusLabKes, 1999) Based on the description of the background above, the writer will conduct a study entitled "Sensitivity and Specificity of Atypical lymphocyte 
in the diagnosis of Dengue Virus Infection in Mataram City Hospital”

\section{SUBJECT AND METHOD}

1. The location and time of the study

This study was conducted in the laboratory of the Mataram Hospital in April - June 2017.

\section{Study Design}

This research is a descriptive observational study with cross sectional approach. Descriptive observational research is research carried out without intervening on research subjects conducted with the aim to find out the description or description of a situation objectively. While cross sectional is a study to study the dynamics of correlation between risk factors and effects, by way of approach, observation or data collection at a time (point time approach) (Notoadmodjo, 2012)

\section{Population and Sample}

The population was all patients diagnosed with dengue virus infection and febrile patients at the Mataram Hospital during May - June. The sampling technique in this study used the Non Random Accidental Sampling technique is a sampling technique that is done by taking cases or respondents who happen to be available in a place in accordance with the research context.

\section{Study Variable}

The independent variables in this study were the sensitivity and specificity of the Atypical lymphocyte method. The dependent variable in this study was the result of examination of Dengue virus infection with Ns-1 and IgGIgM.

\section{Operational Definition}

Sensitivity is the percentage of true positive results from the examination of Atypical lymphocyte measured on the standard Ns-1 and IgG-IgM tests as a control.

Specificity is the ability and accuracy of the results of the examination of Atypical lymphocyte in the diagnosis of Dengue Hemor- rhagic Fever (DHF) without being influenced by other substances that are measured based on the comparison of results on Ns-1 and IgG-IgM examination controls.

DHF diagnosis by means of Atypical lymphocyte was stated positive if $\geq 4 \%$ Atypical lymphocyte per 100 Leukocytes in the peripheral blood smear was found.

Patients with positive dengue virus infection are patients with positive Ns-1 examination criteria accompanied by thrombocytopenia and patients with positive IgGIgM examination accompanied by thrombocytopenia.

Patients with negative dengue virus infection are patients with Ns-1, IgG-IgM screening criteria and negative thrombocytopenia.

\section{Examination Method}

a. Atypical lymphocyte examination

1) Preparation of blood smear

Prepared clean and fat-free glass objects, one drop of blood is dropped on the glass object. Place the spreader (spreader) in front of the blood drop at an angle of $45^{\circ}$ then slide the spreader backward until it touches the blood until the blood spreads along the tip of the spreader. Push the slider to the tip of the glass object with a gentle motion until all the blood spreads into a fairly thin smear.

2) Painting with giemsa

The dried blood are placed in a paint bath, dripped with giemsa solution that has been diluted with a buffer of $7.2 \mathrm{ph}$ with a ratio of 3 drops of parent giemsa to $1 \mathrm{ml}$ of buffer, so that a $15 \%$ giemsa solution can be obtained. Let stand for 15-20 minutes then rinse with running water and dry.

3) Rapid coloring

Rapid coloring consists of 3 reagents, namely rapid I, rapid II and rapid III. Dry preparations are dipped in rapid I dye for 5 minutes, then dipped in rapid II solution for 30 seconds, and dipped in rapid III solution for 5 minutes. Rinse with running water then 
dry the preparation.

b. Ns-1 Examination

Remove the Ns-1 examination cassette from the bug then place it in a dry and flat place. With a disposable dropper drop 3 drops (100 $\mu \mathrm{l})$ of the specimen into well (S). When the reaction occurs, you will see a purple color moves to the reading area. Results are read in 15-20 minutes.

c. IgG-IgM Dengue Examination

The Dengue IgG-IgM tape is removed from the wrapper and then placed in a dry, flat place. With a disposable dropper drop 3 drops $(100 \mu \mathrm{l})$ of the specimen into well (S). When the reaction occurs, you will see a purple color moves to the reading area. Results are read in 15-20 minutes

\section{Data Analysis}

The results of examination of Dengue Hemorrhagic Fever (DHF) using the Atypical lymphocyte method compared to Ns-1 as a control are explained descriptively with a single data.

The data is then entered into the formula as follows:

$$
\begin{aligned}
\text { Atypical lymphocyte Sensitivity }= & \frac{\text { True Positive X 100\% }}{\text { True Positive }+ \text { False Negative }} \\
\text { Atypical lymphocyte Specificity }= & \frac{\text { True Negative X 100\% }}{\text { True Negative + False Positive }}
\end{aligned}
$$

\section{Overview of Study}

This laboratory test was carried out at the Mataram Hospital Laboratory on 8 May to 21 June 2017, where sampling was carried out on 8 May to 15 June, while the reading of the samples was carried out on 17 June to 21 June 2017.

The sample used in this study was a blood sample with the provisions of IgM, IgG and Ns1 positive with thrombocytopenia as positive samples and negative IgM, IgG and Ns1 as negative samples. All blood samples were then made blood smeared and then done with rapid staining. Samples obtained by researchers were 26 samples consisting of 13 positive blood samples and 13 negative blood samples.
The peripheral blood smear slide was then read by a clinical pathology specialist to see the presence of Atypical lymphocyte cells in the preparation. Samples tested positive for Atypical lymphocyte if $4 \%$ or more of Atypical lymphocyte cells were found in the preparation and were negative if not found or Atypical lymphocyte Cells were less than $4 \%$.

Examination of Atypical lymphocyte showed that Out of 13 samples with DI positive, 10 samples were atypical lymphocyte positive. Out of 13 samples with DI negative, 11 samples were atypical lymphocyte negative.

The results of the examination were then entered into the calculation table of sensitivity and specificity, then the sensitivity and specificity of Atypical lymphocyte were calculated using the calculation formula. 


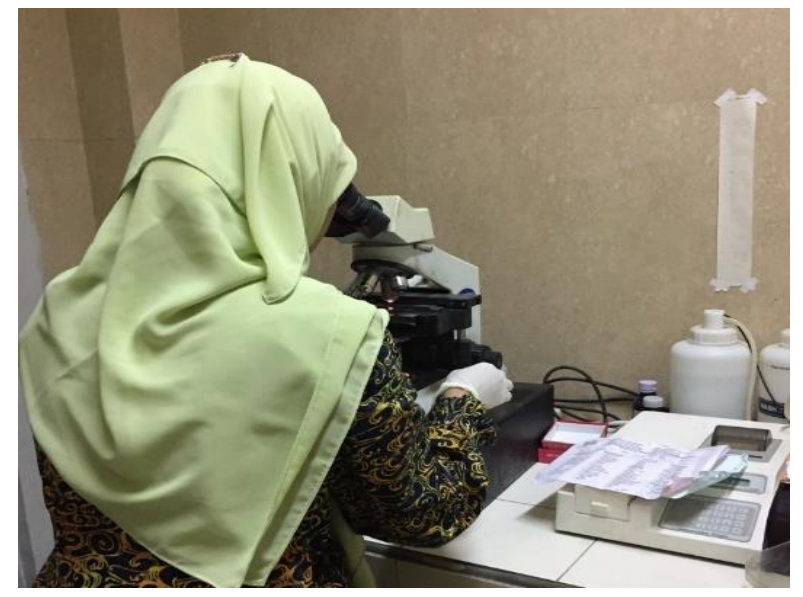

Figure 1. HDT inspection by clinical pathology specialist

From the calculations, the sensitivity of Atypical lymphocyte was $76.92 \%$, while the specificity of Atypical lymphocyte was $84.61 \%$.

\section{DISCUSSIONS}

This laboratory test was conducted at Mataram City Hospital. The samples used were blood samples that tested positive for IgG, IgM and Ns1 accompanied by thrombocytopenia as Positive samples and blood samples with criteria for IgG, IgM and Ns1 negative as negative samples.

Based on the examination of IgG, IgM and Ns1 conducted, it showed that the highest frequency of examination at the General Hospital of Mataram City was IgG IgM examination. This test used 26 samples consisting of 13 samples as positive samples and 13 samples as negative samples.

Examination of Atypical lymphocyte in positive samples showed that 3 of 13 samples tested negative for Atypical lymphocyte. Where all three test samples have the same criteria, namely test samples with $\operatorname{IgG}(+)$ IgM (-) criteria accompanied by thrombocytopenia. The results also found 1 test sample with $\operatorname{IgG}(+) \operatorname{IgM}(-)$ criteria and 1 test sample with positive $\operatorname{IgG}(-) \operatorname{IgM}(+)$ criteria for Blue Plasma Lymphocytes. So that 3 out of 13 positive samples were false negative samples

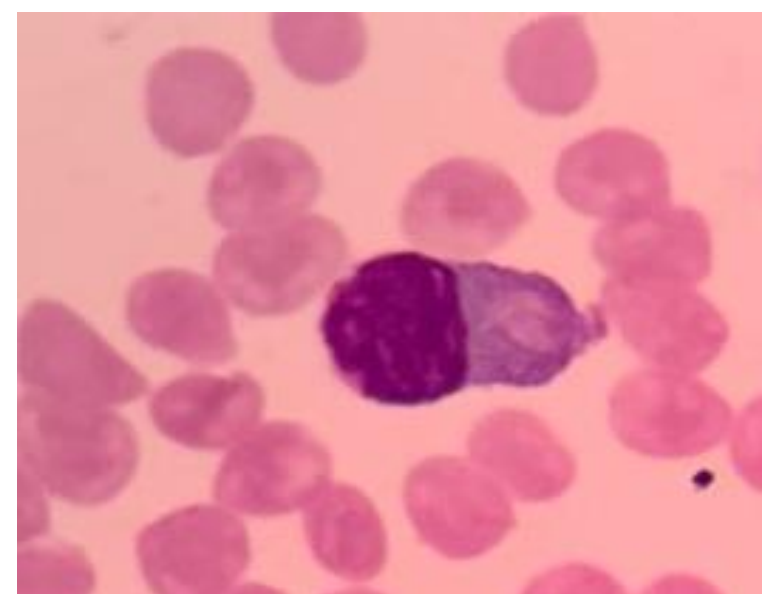

Figure 2. Blue Plasma Lymphocyte Cells

with $\operatorname{IgG}(+) \operatorname{IgM}(-)$ criteria with thrombocytopenia.

Examination based on immunological determination, where the virus that caused DHF to provide a barrier to the body in the form of immunoglobulin. Types of immuneglobulin from viruses can be in the form of immunoglobulin G (IgG) and immuneglobulin M (IgM). The stimulation pathway through the stimulation of immunoglobulinforming cells, namely lymphocytes B. Lymphocytes B would experience stimulation so that a plastic transformation would be seen in peripheral blood (Purwanto, 2002).

According to Setiawan (2011), primary infection showed IgM antibody levels after day 4-5 fever and disappears after $60-90$ days. While IgG antibodies would occur after the 14th day of fever and last for a long time. As with the secondary infection, the antibodies that first formed were IgG and can be found since the beginning of illness or fever. IgG antibodies would occur first, which was 1-2 days after symptoms of fever occur and IgM antibodies would occur after day 5-10 of fever.

Atypical lymphocyte can be seen from day 2 of infection, the absolute number of LPB rised from day 3 of fever to day 7 of fever, after which it would decrease (Nany, 2007). The number of Atypical lymphocyte 
reached its peak on day 6 . The number of Atypical lymphocyte for each clinical spectrum has a significant difference and the number of atypical lymphocyte increased according to the severity of the clinical spectrum (Irianti et al., 2009)

Based on the examination that has been done, it can be seen that Atypical lymphocyte were more sensitive to primary infections. In the theory of secondary infection, it was mentioned that if a person got a primary infection with one type of virus, there would be immunity to infection with that type of virus for a long time. However, if someone was re-infected with a different strain of the virus, severe infection would occur. The number of Atypical lymphocyte reached its peak on day 6 . the number of atypical lymphocyte for each clinical spectrum has a significant difference and the number of atypical lymphocyte increased according to the severity of the clinical spectrum (Irianti et aal., 2009).

The results of the examination of Atypical lymphocyte on negative samples, showed that 11 samples were true negatives and 2 samples were false negatives, both samples were test samples with negative Ns1 examination criteria. After collecting data and examining the number of platelets, it was known that the sample with negative Ns1 criteria has decreased in the number of platelets.

NS1 antigen examination was recommended from the beginning of fever until the eighth day. NS1 antigen sensitivity ranges from 63 to $93.4 \%$ with a specificity of $100 \%$, as high as the specificity of the gold standard of viral culture. However, the negative result of NS1 antigen did not rule out the presence of dengue virus infection, this was thought to be related to the dengue virus serotype that infected (Setiawan, 2011). The difference in sensitivity for each serotype was due to differences in the combination of immune reagents that have low ability for certain serotypes. In addition, it could also be due to geographical differences from the regions (Megarini et al, 2014). Therefore NS1 antigen examination in the acute phase should still be accompanied by other laboratory tests (as needed) as a determinant of primary or secondary infection, as well as to overcome the possibility of false negative results on NS1 antigen examination (Setiawan, 2011).

Irianti et al. (2009) stated that dengue virus infection caused immune system activation. Impaired immune responses such as invasion of the CD4/ CD8 ratio not only interfere with the ability of the immune system to clear the virus, but also cause excessive cytokine production which would influence Tlymphocytes to differentiate into Atypical lymphocyte.

After the testing was done, it can be seen that the number of true positive samples were 10 samples, the true negative sample were 11 samples, the false positive sample was 3 samples and the false negative sample was 2 samples.

From these data, the sensitivity and specificity of Atypical lymphocyte can be calculated. After doing the calculations, the sensitivity value of Atypical lymphocyte was 76.92\% and the specificity value of Atypical lymphocyte was $84.61 \%$.

Based on laboratory tests, the sensitivity of Atypical lymphocyte was 76.92\% and the specificity of Atypical lymphocyte was $84.61 \%$, where the results obtained were different from the results previously presented by Nany (2011), who stated that the sensitivity of Atypical lymphocyte was 50\% and the specificity of Atypical lymphocyte was $90 \%$.

The difference in results can be caused by several factors including the existence of differences in the number of test samples, in this laboratory test, researchers used 26 samples which divided into 2 types of sam- 
ples, positive and negative samples while the previous researcher used 63 samples, so the difference the number of samples would affect the calculation. In addition there were differences in sample criteria used where the researchers used samples with criteria IgG, IgM, Ns1 with thrombocytopenia as positive samples and IgG, IgM, negative as negative samples, whereas previous researchers used samples with criteria NS1Ag positive tests and Ns1Ag negative tests.

According to Lapau (2013), the greater the number of samples, the less random errors that exist in the study. In this laboratory test, it was known that there were several factors that greatly affect the results of the examination of Atypical lymphocyte namely examining factors, factors of making the preparation of blood smears and painting factors of blood smear preparations.

Atypical lymphocyte Cells would be difficult to recognize by examiners who have lack of understanding, experience and only rely on cell characteristics in theory because not all Atypical lymphocyte cells were exactly the same as Theory. Making blood smears was also very determining the examination. A good blood smear was a 2/3 slide length smear, if the blood smear was not well made then it would reduce the cell reading area because the reading area for Atypical lymphocyte Cells was all parts of the blood smear. In addition to examining and making preparations, painting iwas also an important factor in examining Atypical lymphocyte cells.

A good painting would clear the cytoplasm cells that were blue so that the better the painting, the easier to it was to recognize. Poor painting would cause the color in the cytoplasm of cells to fade and difficult to distinguish from normal lymphocyte cells so that it would cause a problem.

\section{REFERENCES}

Afira F, Mansyur M (2013). Gambaran Kejadian Demam Berdarah Dengue di Kecamatan Gambir dan Kecamatan Sawah Besar, Jakarta Pusat, Tahun 2005-2009 (Overview of Dengue Hemorrhagic Fever Occurrence in Gambir District and Sawah Besar District, Central Jakarta, 2005-2009. eJournal Kedokteran Indonesia, 23-29.

Arruan RD, Rambert G, Manoppo F (2015). Limfosit Plasma Biru dan Jumlah Leukosit Pada Pasien Anak Infeksi Virus Dengue di Manado (Atypical lymphocyte and Leukocyte Counts in Pediatric Patients with Dengue Virus Infection in Manado). Jurnal e-Biomedik, 3(1).

Dewi LBK (2010). Imuno Sensor Untuk Mendeteksi Imunoglobulin G Terhadap Toxoplasma gondii dengan Metode GICA Menggunakan Ekstrak Esa Sebagai Bioreseptor (Immuno Sensor to Detect Immunoglobulin $\mathrm{G}$ against Toxoplasma gondii with GICA Method Using Esa Extract as Bioreceptors), Tesis Universitas Airlangga.

Irianti DM, Reniarti L, Azhali MS (2016). Hubungan Jumlah Limfosit Plasma Biru dengan Spektrum Klinis dan Perannya dalam Memprediksi Perubahan Spektrum Klinis Infeksi Dengue pada Anak (Relationship of Atypical lymphocyte Amount with Clinical Spectrum and Its Role in Predicting Clinical Spectrum Changes in Dengue Infection in Children). Sari pediatri, 10(5): 325-30.

Lapau B (2013). Metode Penelitian Kesehatan Revisi (Revised Health Research Methods). Yayasan Pustaka Obor Indonesia. Jakarta.

Mariko R, Alkamar A, Putra AE. (2014). Uji Diagnostik Pemeriksaan Antigen Nonstruktural 1 untuk Deteksi Dini Infeksi 
Virus Dengue pada Anak (Nonstructural Antigen 1 Diagnostic Test for Early Detection of Dengue Virus Infection in Children). Sari Pediatri, 16(2): 121-127. Massi MN, Sabran A (2006). Teknik Identifikasi Serotipe Virus Dengue (Den 1-4) dengan Uji Reverse Polymerase Chain Reaction (RT-PCR) (Dengue Virus Serotype Identification Technique (Den 14) with Reverse Polymerase Chain Reaction (RT-PCR) Test). Fakultas Kedokteran Universitas Hasanudin.

Nany (2003). Limfosit Plasma Biru Nilai Diagnostik pada Infeksi Dengue (Atypical lymphocyte Diagnostic Value in Dengue Infection). Jurnal of Chamical Information and Modeling. Universitas Sumatra Utara. https://doi.org/10.1017/CBO9781107415324.004

Purwanto P (2002). Pemeriksaan Laboratorium pada Penderita Demam Berdarah Dengue (Laboratory Examination in Dengue Hemorrhagic Fever Patients). Media Penelitian dan Pengem- bangan Kesehatan, 12.

Sembel DT (2009). Entomologi kedokteran (Medical Entomology). Yogyakarta: CV. Andi Offset.

Setiawan M (2012). Demam Berdarah Dengue (DBD) dan Ns1 Antigen Untuk Deteksi Dini Infeksi Akut Virus Dengue (Dengue Hemorrhagic Fever (DBD) and Ns1 Antigen for Early Detection of Acute Dengue Virus Infection). Saintika Medika: Jurnal Ilmu Kesehatan dan Kedokteran Keluarga, 6(1).

Widodo NP (2012). Faktor-Faktor yang Berhubungan Dengan Kejadian Demam Berdarah Dengue (DBD) di Kota Mataram Provinsi Nusa Tenggara Barat Tahun 2012 (Factors Related to the Occurrence of Dengue Fever (DHF) in Mataram City, West Nusa Tenggara Province in 2012).

Wiradharma D (1999). Diagnosis Cepat Demam Berdarah Dengue (Rapid diagnosis of dengue fever). J Kedok Trisakti, 18: 77-90. 